\title{
Steroid production by isolated theca and granulosa cells after initiation of atresia in the hamster*
}

\author{
S. L. Silavin $\dagger$ and G. S. Greenwald \\ Department of Physiology, Ralph L. Smith Research Center, University of Kansas Medical Center, \\ Kansas City, Kansas 66103, U.S.A.
}

\begin{abstract}
Summary. Hypophysectomized PMSG-primed hamsters were injected with PMSG antiserum and the theca and granulosa cells of the resulting atretic follicles were incubated in vitro. In the absence of added hormone, $17 \alpha$-hydroxyprogesterone and oestradiol production was not detectable in granulosa cells collected and incubated at 0 , 12 and $24 \mathrm{~h}$ after antiserum. Progesterone production was not detected in control incubations at $0 \mathrm{~h}$ but was measurable with cells collected at $12 \mathrm{~h}$ after PMSG antiserum. When incubated with androstenedione or pregnenolone ( $10 \mathrm{ng} / \mathrm{ml}$ for each) $17 \alpha$-hydroxyprogesterone and progesterone production by granulosa cells were significantly increased at 0,12 and $24 \mathrm{~h}$ after antiserum. Granulosa cells were capable of aromatizing androstenedione to oestradiol at all times examined. At 0 and $12 \mathrm{~h}$ after antiserum to PMSG, isolated thecal shells produced androstenedione. LH stimulation caused increased androstenedione production in all thecae at $0 \mathrm{~h}$, in $50 \%$ of the thecae at $12 \mathrm{~h}$ and in none at $24 \mathrm{~h}$ after antiserum. Thecal shells produced $17 \alpha-$ hydroxyprogesterone in response to $\mathrm{LH}$ at 0,12 and $24 \mathrm{~h}$ after antiserum, and produced progesterone at all times examined. Thecae also responded to $\mathrm{LH}$ with increased progesterone production up to $72 \mathrm{~h}$ after antiserum. These experiments demonstrate that one important steroidogenic event in atresia may be the loss of activity of $\mathrm{C} 17,20$ lyase in the theca leading to loss of substrate (androstenedione) for granulosa cell aromatization, although aromatase activity is present until at least $24 \mathrm{~h}$ after the induction of atresia.
\end{abstract}

\section{Introduction}

A model for initiation of atresia in the hamster has been developed by Greenwald (1973) and characterized by Bill \& Greenwald (1981). Hamsters were injected with PMSG immediately after hypophysectomy on the morning of oestrus and 3 days later received an injection of antiserum to PMSG, thus, making it possible to define the onset of atresia in a synchronous population of follicles. Previous studies using this model for initiation of atresia have shown that atretic follicles incubated in vitro first lost the ability to produce oestrogens (by $1 \mathrm{~h}$ after anti-PMSG), and then androgens (by $2 \mathrm{~h}$ after anti-PMSG; Hubbard \& Greenwald, 1981). However, progesterone production increased by $4 \mathrm{~h}$ after anti-PMSG and was maintained for at least $72 \mathrm{~h}$ after the antiserum (Hubbard \& Greenwald, 1981). This pattern of steroidogenic ability was also seen with follicles incubated in the presence of LH (Hubbard \& Greenwald, 1983). It was suggested that the thecal compartment was primarily responsible for the increase in progesterone production during

* Reprint requests to Dr G. S. Greenwald.

† Present address: Department of Obstetrics and Gynecology, Hospital of the University of Pennsylvania, 3400 Spruce St, Philadelphia, PA 19104, U.S.A. 
experimentally induced atresia in the hamster (Terranova, Martin \& Chien, 1982). The aim of the present study was to examine the steroidogenic ability of the isolated components of the follicle, theca and granulosa cells, to determine which factors contribute to the decline in oestradiol production and the increase in progesterone production seen with atretic hamster follicles.

\section{Materials and Methods}

Female hamsters (Mesocricetus auratus) were maintained on a $14 \mathrm{~h}$ light: $10 \mathrm{~h}$ dark schedule with lights on from $05: 00$ to $19: 00 \mathrm{~h}$. At least 3 consecutive 4-day oestrous cycles were monitored before using the animals.

Hamsters were hypophysectomized between $09: 00$ and 11:00 h on Day 1 of the oestrous cycle (day of ovulation) by the parapharyngeal approach under ketamine anaesthesia (Ketaject: Bristol Laboratories, Syracuse, New York). Hamsters were injected s.c. with 30 i.u. PMSG (Sigma Chemical Co., St Louis, MO) immediately after surgery. At 09:00 h on Day 4 (72 h after surgery) animals were injected i.p. with $100 \mu \mathrm{l}$ undiluted antiserum to PMSG (obtained from rabbits and supplied by Dr C. J. Hubbard and Dr D. C. Johnson). Hamsters were decapitated at 12, 24, 48 or $72 \mathrm{~h}$ after PMSG antiserum. Control groups consisted of hypophysectomized-PMSG-treated animals receiving no antiserum and killed at $09: 00 \mathrm{~h}$ on Day $4(0 \mathrm{~h})$.

At necropsy, the sella turcica was examined with a dissecting microscope for fragments of pituitary, and animals in which any gross remnants were present were rejected.

Preparation and incubation of granulosa cells and theca. Ovaries were removed immediately after decapitation and Graafian follicles were dissected free and placed in cold $\left(4^{\circ} \mathrm{C}\right)$ Medium 199 containing 25 mm-Hepes buffer (Grand Island Biological Co., Grand Island, NY). Follicles were sliced open using a $3 \mathrm{~mm}$ knife needle. Expression of granulosa cells was aided by gentle shaking of the opened follicle. Granulosa cells were washed, centrifuged $(50 \mathrm{~g}, 7 \mathrm{~min})$ and resuspended in Medium 199. Cells were counted in a haemocytometer and viability assessed by the trypan blue dye exclusion method. Viability was $39 \cdot 4 \pm 2 \cdot 1 \%$ at $0 \mathrm{~h}, 44 \cdot 0 \pm 1 \%$ at $12 \mathrm{~h}$ and $37 \cdot 3 \pm 3 \cdot 3 \%$ at $24 \mathrm{~h}$ after antiserum. The granulosa cells (20000-30000 viable cells) were incubated for $1 \mathrm{~h}$ in a Dubnoff metabolic shaker, in $12 \times 75 \mathrm{~mm}$ polypropylene tubes containing $1 \mathrm{ml}$ Medium 199 at $37^{\circ} \mathrm{C}$ with no hormone, $10 \mathrm{ng}$ androstenedione or $10 \mathrm{ng}$ pregnenolone. Granulosa cells from ovaries of 3 or 4 animals were pooled at each time and each experiment was repeated at least 3 times.

Thecal shells from these follicles were gently scraped to remove adhering granulosa cells. Thecae were washed several times in Medium 199 and 3 thecae from each animal were incubated in $12 \times 75 \mathrm{~mm}$ conical tubes containing $1 \mathrm{ml}$ Medium 199 for $1 \mathrm{~h}$ at $37^{\circ} \mathrm{C}$ (with or without $1 \mu \mathrm{g} \mathrm{LH}$ ).

All incubations were stopped by rapid freezing of tubes in a solid $\mathrm{CO}_{2}$-ethanol bath. Before steroid determinations, tubes were thawed and contents sonicated for $5 \mathrm{sec}$ with a Kontes microultrasonic cell disruptor at a setting of $313 \mathrm{~W} / 6.45 \mathrm{~cm}^{2}$.

Steroid radioimmunoassays. The antisera used in the assays were for progesterone (Surve, Bacso, Brinkerhoff \& Kirsch, 1976), androstenedione (provided by Dr J. Resko, Oregon Regional Primate Research Center, Beaverton, OR), oestradiol (Wright, Collins \& Preedy, 1973) and 17 $\alpha$ hydroxyprogesterone (Steranti Research Ltd, Hertfordshire, U.K.). The RIA procedures were identical to those previously described (Terranova, Connor \& Greenwald, 1978; Johnson, 1979). Sensitivities of the assays were $5 \mathrm{pg}$ for progesterone and $17 \alpha$-hydroxyprogesterone, $4 \mathrm{pg}$ for androstenedione and $2 \mathrm{pg}$ for oestradiol. For measurements of steroids in the incubation medium plus cell samples and in medium blanks, $100 \mu 1$ were used for progesterone, $17 \alpha$-hydroxyprogesterone and androstenedione assays and 100-300 $\mu \mathrm{l}$ for oestradiol assays. The inter-assay and intraassay coefficients of variation for the assays were $\leqslant 7.7 \%$. Medium containing $10 \mathrm{ng}$ pregnenolone or $10 \mathrm{ng}$ androstenedione without cells had no measurable oestradiol. Tests of medium containing $10 \mathrm{ng}$ pregnenolone in the progesterone and $17 \alpha$-hydroxyprogesterone assays, and of medium 
containing $10 \mathrm{ng}$ androstenedione in the progesterone assay, all resulted in values between 1 and $2 \%$ of those obtained in the presence of the added steroids plus cells. These small blank values were not subtracted from the experimental results.

Statistics. Specific differences were determined by Duncan's multiple range test (Steel \& Torrie, 1960 ) following one-way analysis of variance. Differences were adjudged significant if $P<0.05$.

\section{Results}

Steroid production by granulosa cells from atretic follicles

Due to extremely low yield and greatly diminished viability at $48 \mathrm{~h}$ after PMSG antiserum, granulosa cells were examined only at 0,12 and $24 \mathrm{~h}$ after the onset of atresia. Oestradiol was nondetectable at 0,12 and $24 \mathrm{~h}$ after PMSG antiserum in control incubations, but the addition of $10 \mathrm{ng}$ androstenedione resulted in oestradiol production by these cells and aromatizing ability appeared to increase, although not significantly, over the 24 -h period (Text-fig. 1a). The addition of $10 \mathrm{ng}$ pregnenolone significantly increased oestradiol production at 0 and $24 \mathrm{~h}$ after antiserum (Text-fig. 1a). Granulosa cells produced low but detectable levels of progesterone at 12 and $24 \mathrm{~h}$ after PMSG antiserum. At all times examined, the addition of pregnenolone resulted in a large conversion of pregnenolone to progesterone (Text-fig. 1b). The addition of pregnenolone to granulosa cell incubations also led to increased $17 \alpha$-hydroxyprogesterone production which was not detectable in control incubations (Text-fig. 1c). The addition of androstenedione resulted in increased production of progesterone and $17 \alpha$-hydroxyprogesterone by granulosa cells at 0,12 and $24 \mathrm{~h}$ after antiserum (Text-figs $1 \mathrm{~b} \& \mathrm{c})$. Granulosa cells responded to LH stimulation $(10 \mathrm{or} 100 \mathrm{ng} / \mathrm{ml})$ with increased progesterone production only at time zero (control: $26.3 \pm 3.8 \mathrm{pg} / 10000$ cells, $n=10$; $10 \mathrm{ng} \mathrm{LH} / \mathrm{ml}, 56 \cdot 1 \pm 11 \cdot 1 \mathrm{pg} / 10000$ cells, $n=3$ ).

(a)

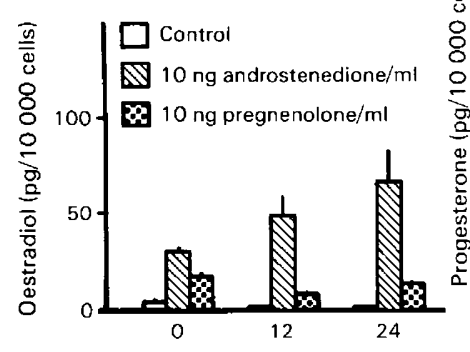

Text-fig. 1. The production of (a) oestradiol progesterone by granulosa cells incubated for $1 \mathrm{~h}$ wh progesterone and (c) 17 $\alpha$-hydroxyor $10 \mathrm{ng}$ pregnenolone $/ \mathrm{ml}$ at 0,12 or $24 \mathrm{~h}$ after initiation of atresia with PMSG antiserum. Values are mean \pm s.e.m., $n=7$ at $0 \mathrm{~h}, n=4$ at $12 \mathrm{~h}$ and $n=6$ at $24 \mathrm{~h}$.

\section{Steroid production by theca from atretic follicles}

Thecal shells did not produce detectable levels of oestradiol at any time examined. Thecae produced androstenedione at 0 and $12 \mathrm{~h}$ after PMSG antiserum, but by $24 \mathrm{~h}$ androstenedione levels were undetectable (Text-fig. 2a). The addition of $\mathrm{LH}$ resulted in increased androstenedione production by theca at $0 \mathrm{~h}$ (Text-fig. 2a). At $12 \mathrm{~h}$ after PMSG antiserum, some of the thecae incubated responded to LH stimulation with increased androstenedione production, while the 

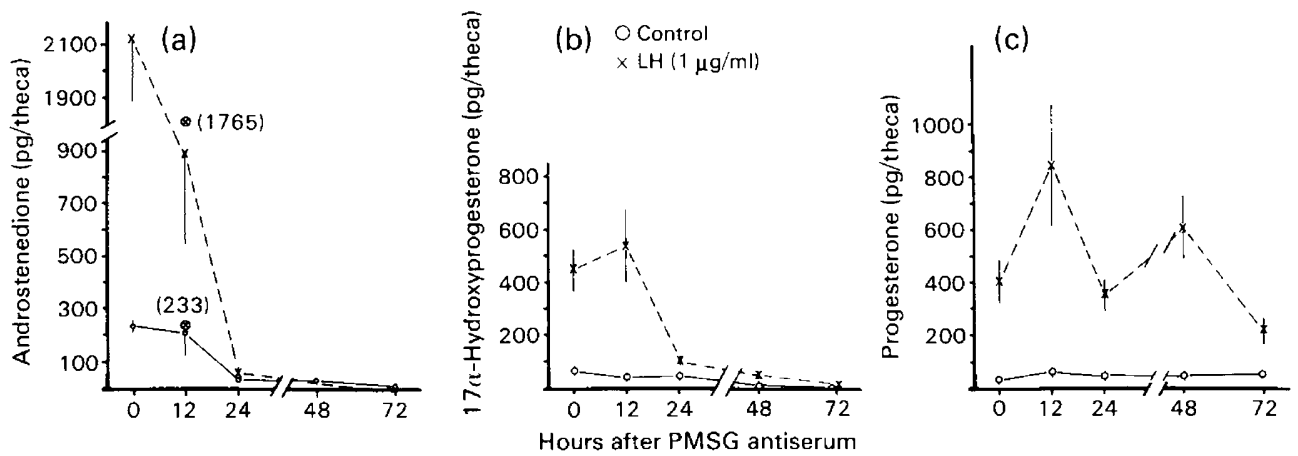

Text-fig. 2. Production of (a) androstenedione, (b) $17 \alpha$-hydroxyprogesterone and (c) progesterone by thecae ( 3 thecal shells/tube) incubated for $1 \mathrm{~h}$ with or without $1 \mu \mathrm{g}$ ovine $\mathrm{LH} / \mathrm{ml}$ at 0,12 , 24, 48 or $72 \mathrm{~h}$ after PMSG antiserum. Values are mean \pm s.e.m. for 4-9 determinations per group. In (a), $\otimes$ indicates the mean value of androstenedione produced by thecae responding to $\mathrm{LH}$ at $12 \mathrm{~h}(1765 \mathrm{pg} /$ theca, $n=3)$ and the mean value of those that did not respond to $\mathrm{LH}$ $(233 \mathrm{pg} /$ theca, $n=4)$.

remaining thecae did not produce androstenedione above control values (Text-fig. 2a). This result was obtained in several separate experiments. By $24 \mathrm{~h}$ after PMSG antiserum, thecae did not produce androstenedione in response to $\mathrm{LH}$.

Thecal production of $17 \alpha$-hydroxyprogesterone was low but detectable for $24 \mathrm{~h}$ after PMSG antiserum and undetectable by $48 \mathrm{~h}$ in control incubations (Text-fig. $2 \mathrm{~b}$ ). In response to $\mathrm{LH}$, thecal shells produced large amounts of $17 \alpha$-hydroxyprogesterone $(450-550 \mathrm{pg} /$ theca) at 0 and $12 \mathrm{~h}$ after anti-PMSG (Text-fig. 2b). At $24 \mathrm{~h}$ after antiserum, 17 $\alpha$-hydroxyprogesterone production in response to $\mathrm{LH}$ was double that of 24 -h control incubations but was not significantly different from $0 \mathrm{~h}$ control values (Text-fig. 2b). Thecae also produced progesterone in low but detectable amounts (30-60 pg/theca) at all times examined (Text-fig. 2c) and responded to LH stimulation with increased progesterone production at all times although the percentage stimulation above control was significantly reduced at $72 \mathrm{~h}$ after antiserum (Text-fig. 2c). Until $12 \mathrm{~h}$ after anti-PMSG androstenedione was the dominant steroid produced by the theca.

\section{Discussion}

The increase in the production of progesterone, 17 $\alpha$-hydroxyprogesterone and oestradiol by granulosa cells in the presence of pregnenolone suggested that these cells contained the enzymes necessary for follicular steroidogenesis for $24 \mathrm{~h}$ after initiation of atresia. This occurred at a time when, as previously shown, serum oestradiol is very low (12 h after PMSG antiserum) or not detectable (24 h after PMSG antiserum: Bill \& Greenwald, 1981; Hubbard \& Greenwald, 1981).

The addition of androstenedione to granulosa cells resulted in progesterone and $17 \alpha-$ hydroxyprogesterone production that was significantly greater than that seen in control incubations at 0,12 and $24 \mathrm{~h}$ after PMSG antiserum (Text-figs $1 \mathrm{~b} \& \mathrm{lc}$ ). Increased progesterone and $17 \alpha$-hydroxyprogesterone production in the presence of androstenedione has been observed in rat granulosa cells (Armstrong \& Dorrington, 1976; Lucky, Schreiber, Hillier, Schulman \& Ross, 1977; Nimrod, 1981) and pig antral follicles (Schomberg, Stouffer \& Tyrey, 1976). The mechanism by which androgen exerts its effect is not fully understood. Androgens may facilitate the ability of FSH to increase progesterone production by granulosa cells cultured for $48 \mathrm{~h}$ by increasing cholesterol side-chain cleavage enzyme activity (Nimrod, 1981). In the present study, the increase in progesterone production by granulosa cells in response to androstenedione occurred (within $1 \mathrm{~h}$ of incubation) and the cells responded equally well at 0,12 or $24 \mathrm{~h}$ after antiserum. It is also possible 
that androstenedione competes with enzymes involved in the catabolism of progesterone, thus allowing for the apparent increase, although there is no evidence that this is the case. However, granulosa cells from follicles of pro-oestrous hamsters not pretreated with PMSG do not increase progesterone production when exposed in vitro to androstenedione (G. S. Greenwald, unpublished).

It therefore appears that granulosa cells from atretic follicles in the hamster have the ability to produce oestradiol at $0,12 \mathrm{~h}$ and $24 \mathrm{~h}$ after anti-PMSG as long as precursor, androstenedione or pregnenolone, is provided. Makris \& Ryan (1977) have shown that granulosa cells from follicles of pro-oestrous hamsters rely on thecal androstenedione as the source of precursor for aromatization. It has also been shown that atretic follicles from rats treated for 3 or 4 days with phenobarbitone produced one-fifth as much oestradiol as do preovulatory follicles unless precursor (testosterone) was added to the incubation medium (Braw \& Tsafriri, 1980). These investigators did not incubate follicles in the presence of pregnenolone to determine whether 17-hydroxylase and C17,20 lyase enzyme activities were impaired. The results in the present study indicate that granulosa cells contain active enzymes capable of converting progesterone to oestradiol and although these cells did produce small amounts of progesterone, at 12 and $24 \mathrm{~h}$ after PMSG antiserum, it was not enough to maintain oestradiol synthesis (Text-figs la \& lb). Moreover, $\mathrm{LH}$ was unable to stimulate an increase in progesterone production beyond $0 \mathrm{~h}$. This result was consistent with data by Shaha \& Greenwald (1982) showing a decline in hCG and FSH binding to granulosa cells from 0 to $24 \mathrm{~h}$ after PMSG antiserum. Therefore, the ability of atretic follicles to produce progesterone and respond to LH after anti-PMSG (Hubbard \& Greenwald, 1983) must be due primarily to the steroidogenic capacity of the theca.

At $12 \mathrm{~h}$ after PMSG antiserum, approximately half of the thecal shells examined produced a significant amount of androstenedione in response to LH. The remaining thecae in this group did not respond to $\mathrm{LH}$ with androstenedione production above control values. Thus, $12 \mathrm{~h}$ after antiserum appeared to be a critical time in the ability of theca to produce androgens in response to LH. However, thecae produce progesterone in control incubations and increased progesterone in response to $\mathrm{LH}$ for $72 \mathrm{~h}$ after initiation of atresia by anti-PMSG, and thecal progesterone production has been shown to increase as atresia developed after ovulatory delay produced by phenobarbitone injections of hamsters (Terranova et al., 1982). LH stimulates cAMP production in atretic follicles for $72 \mathrm{~h}$ after PMSG antiserum (Hubbard \& Greenwald, 1981) and hCG binding to theca is unchanged over this same period of time (Shaha \& Greenwald, 1982). Similarly, hCG binding to thecae from atretic rat follicles was unchanged over 4 days of ovulatory delay induced by phenobarbitone (Uilenbroek, Woutersen \& Van der Schoot, 1980). Therefore, the thecae maintain the ability to produce progesterone even when all other steroids are undetectable and granulosa cells are essentially defunct.

The acute gonadotrophin deprivation as a result of PMSG antiserum caused a more rapid progession of atresia than that seen as a result of ovulatory delay due to daily phenobarbitone injections, although the sequence of steroidogenic events correlates well. The most notable change seen as atresia developed in both systems was the shift from follicular oestradiol production to progesterone production. This shift occurred mainly as a result of thecal progesterone production (Terranova et al., 1982; present study). In the cyclic animal, after the ovulatory gonadotrophin surge, granulosa cells and theca differentiate into primarily progesterone-producing cells and thus also display a shift from oestradiol to progesterone production. During atresia, this shift occurred in the absence of the gonadotrophin surge but only thecal cells retained the ability to produce progesterone.

Although granulosa cells began to undergo regressive changes by $4 \mathrm{~h}$ after PMSG antiserum (Bill \& Greenwald, 1981), the viable cells retain enzyme activity for at least $24 \mathrm{~h}$ after antiserum. In normal granulosa cells at pro-oestrus, neither progesterone nor $17 \alpha$-hydroxyprogesterone is converted to oestradiol; a block exists at the desmolase level (G. S. Greenwald, unpublished). This study has reaffirmed that, although granulosa cells have the enzymic ability to produce androstenedione as well as oestradiol, the theca is the major source of androgen for aromatization to 
oestradiol by granulosa cells. Once androstenedione production by the theca was lost, $24 \mathrm{~h}$ after anti-PMSG, granulosa cells also lost the ability to produce oestradiol. Although a number of changes occur during atresia, one of the key steroidogenic events may be the loss of activity of $\mathrm{C} 17,20$ lyase enzyme in the theca leading to the inability of theca to supply the substrate, androstenedione, to granulosa cells.

This research was supported by a grant from NIH (HD00596-21). We thank the National Pituitary Agency for providing the ovine $\mathrm{LH}$.

\section{References}

Armstrong, D.T. \& Dorrington, J.H. (1976) Androgens augment FSH-induced progesterone secretion by cultured rat granulosa cells. Endocrinology $99,1411-$ 1414.

Bill, C.H., III \& Greenwald, G.S. (1981) Acute gonadotrophin deprivation. I. A model for the study of follicular atresia. Biol. Reprod. 24, 913-921.

Braw, R.H. \& Tsafriri, A. (1980) Follicles explanted from pentobarbitone-treated rats provide a model for atresia. J. Reprod. Fert. 59, 259-265.

Greenwald, G.S. (1973) Effects of anti-PMS serum on ovulation and estrogen secretion in the PMS-treated hamster. Biol. Reprod. 9, 437-446.

Hubbard, C.J. \& Greenwald, G.S. (1981) Changes in DNA, cyclic nucleotides and steroids during induced follicular atresia in the hamster. J. Reprod. Fert. 63, 455-461.

Hubbard, C.J. \& Greenwald, G.S. (1983) In vitro effects of luteinizing hormone on induced atretic Graafian follicles in the hamster. Biol. Reprod. 28, 849-859.

Johnson, D.C. (1979) Maintenance of functional corpora lutea in androgenized female rats treated with PMSG. J. Reprod. Fert. 56, 263-269.

Lucky, A.W., Schreiber, J.R., Hilier, S.C., Schulman, J.D. \& Ross, G.T. (1977) Progesterone production by cultured preantral rat granulosa cells: stimulation by androgens. Endocrinology 100, 128-133.

Makris, A. \& Ryan, K.J. (1977) Aromatase activity of isolated and recombined hamster granulosa cells and theca. Steroids 29, 65-72.

Nimrod, A. (1981) On the synergistic action of androgen and FSH on progestin secretion by cultured rat granulosa cells. Molec. cell. Endocr. 21, 51-62.
Schomberg, D.W., Stouffer, R.L. \& Tyrey, L. (1976) Modulation of progestin secretion in ovarian cells by 17 $\beta$-hydroxy- $5 \alpha$-androstan-3-one (dihydrotestosterone): a direct demonstration in monolayer culture. Biochem. Biophys. Res. Commun. 68, 77-81.

Shaha, C. \& Greenwald, G.S. (1982) Autoradiographic analysis of changes in ovarian binding of FSH and hCG during induced follicular atresia in the hamster. J. Reprod. Fert. 66, 197-201.

Steel, R.G. \& Torrie, J.H. (1960) Principles and Procedures of Statistics. McGraw-Hill, New York.

Surve, A.H., Bacso, I., Brinkerhoff, J.H. \& Kirsch, S.J. (1976) Plasma levels of progesterone in pseudopregnant rabbits actively immunized with a progesterone protein conjugate. Biol. Reprod. 15, 343-349.

Terranova, P.F., Connor, J.S. \& Greenwald, G.S. (1978) In vitro steroidogenesis in corpora lutea and nonluteal ovarian tissues of the cyclic hamster. Biol. Reprod. 19, 249-255.

Terranova, P.F., Martin, N.C. \& Chien, S. (1982) Theca is the source of progesterone in experimentally induced atretic follicles of the hamster. Biol. Reprod. 56, 721727.

Uilenbroek, J., Woutersen, P. \& Van der Schoot, P. (1980) Atresia of preovulatory follicles: gonadotropin binding and steroidogenic activity. Biol. Reprod. 23, 219 229.

Wright, K., Collins, D.C. \& Preedy, J.R.K. (1973) Comparative specificity of antisera raised against estrone, estradiol-17 $\beta$ and estriol using 6-O-carboxymethyloxine bovine serum albumin derivatives. Steroids 21, 755-769.

Received 31 August 1983 